\title{
Against the current: The emergence of a media democratization policy agenda in Latin America
}

Global Media and Communication

$1-20$

(C) The Author(s) 2017

Reprints and permissions: sagepub.co.uk/journalsPermissions.nav DOI: $10.1177 / 1742766517734253$ journals.sagepub.com/home/gmc

@SAGE

\section{Philip Kitzberger}

Universidad Torcuato Di Tella, Argentina; Consejo Nacional de Investigaciones Científicas y Técnicas, Argentina

\begin{abstract}
In Latin America, the role of the media in democratic societies has recently become the subject of public debates, struggles and political mobilizations that have denaturalized the existing media order and established a distinct policy agenda oriented towards media democratization. This region-wide trend - a counter-tendency to the globally dominant market-driven orientation of media and telecommunication policies - requires explanation. This article stresses that it cannot be attributed to a spontaneous reaction to market concentration or media elitism, just as it cannot be reduced to a top-down process driven by populist leaders seeking to control the media. Drawing on social movement literature, the article traces four interacting processes - domestic network mobilization, reframing processes, transnational activism and changes in political elite alignments - that have brought about the unprecedented politicization of the Latin American media order.
\end{abstract}

\section{Keywords}

Democratization, Latin America, media policy, media reform movements, media regulation

Since the beginning of the century, the role of the media in democratic societies has become the subject of contentious political activity in Latin America. In many of the

\footnotetext{
Corresponding author:

Philip Kitzberger, Departamento de Ciencia Política y Estudios Internacionales, Universidad Torcuato Di

Tella, Av. Figueroa Alcorta 7350, 1428 Ciudad Autónoma de Buenos Aires, Argentina.

Email: pkitzberger@utdt.edu
} 
region's countries, a series of media policy reform initiatives has been pushed forward. And in many cases, these initiatives have succeeded in bringing about legal reforms. Between 2004 and 2014, Argentina, Bolivia, Ecuador, Venezuela and Uruguay passed new laws regulating the media. The media democratization demands even found expression in Ecuador and Bolivia's constitutional reforms. These and other policies enhancing the state's role in the media realm or recognizing and fostering alternative forms of communication, such as community media, have been widely noticed (Hintz, 2015; Kitzberger, 2010; Mastrini, 2013; Ramos, 2010; Gómez García 2013; Waisbord, 2011, 2013). Taken together, they represent an unprecedented policy change in a region where media regulation has traditionally consisted mostly of the a posteriori legal sanctioning of agreements between the political and media elites.

Beyond particular features, all of the recent reform initiatives in the region share a common orientation: a newly emerged emphasis on the active role of the state as a guarantor of democratic imperatives in the media sphere. The main underlying assumption is that a properly democratic media system plays a key role in countering power asymmetries in the context of the planet's most inegalitarian societies. This common core is expressed in normative arguments about freedom of expression, in policy goals and instruments, all of which are present in discourse, legal reforms or jurisprudence. These normative concerns are framed in terms of 'media democratization' or 'communication rights', in conformance with a distinct media policy agenda.

This agenda is not just distinct from the region's past policies. It also represents a counter-tendency to the current, globally dominant market-driven orientation of media and telecommunication policies, which emphasize economic efficiency and technological concerns (van Cuilenberg and McQuail, 2003). The recent rightward political shift in the region might signal a reversal of this trend, as the ongoing attempts to dismantle the achieved media reforms in the countries that switched government attest.

Despite such present challenges to its continuity, the emergence of this contrasting regional policy agenda requires explanation. This article deals with the question of why and how it has emerged. The article stresses that the rise of this alternative agenda cannot be viewed simply as a spontaneous reaction to the grievances of market concentration or media elitism. Nor can it be reduced - as journalistic accounts often do - to a top-down process driven by populist leaders instrumentally seeking to control the media. Academic research has described some aspects of this policy reorientation and pointed to some of its causes (Hintz, 2015; Klinger, 2011; Mauersberger, 2011; Segura, 2014; Waisbord, 2010, 2013). However, a complete picture of the processes and mutually reinforcing mechanisms is still lacking.

Drawing on elements of social movement theory, the aim of this article is to show how, beyond the structural grievances, the emergence of a regional agenda can be traced back to a series of interacting processes. Domestic network mobilization, reframing processes, transnational activism and changes in political elite alignments have interacted through diffusion, learning and mutually reinforcing mechanisms that have brought about an unprecedented politicization of the Latin American media order.

Some of the features and processes were present throughout the region. However, only a subset of countries, mostly in South America, presented the whole set of stressed interactions. For example, Mexico, Peru and Colombia share traits in the development of 
their respective media markets and some of the civil society's mobilization efforts, yet the three lacked the shift in the political opportunity structure needed for the posited outcome. The Central American countries possessed extremely elitist and concentrated media system structures; yet, with the partial exception of El Salvador, they lacked either the conditions of significant social networks or favourable political contexts, or both.

The events and processes focused on here require a qualitative analysis. Therefore, a process-tracing strategy is applied here to reconstruct the trajectories of change and causation through the description of temporal sequences and the assessment of the causal mechanisms at play (Goertz and Mahoney, 2012). In addition to secondary sources and documents, the empirical observations rely mainly on a series of informant interviews by the author with a range of participants involved in media policy reform from Argentina, Brazil, Ecuador and Uruguay. ${ }^{1}$

The following section presents a conceptual framework based on social movement theory. The subsequent section describes the structural inequalities within Latin America's media systems. The ensuing sections reconstruct the developments of domestic networks, transnational activisms and political realignments to finally address the interactions that shaped and enabled the spread of the media reform agenda in the region.

\section{Theoretical considerations: Networks, organizations and politics}

The emergence of a policy agenda constitutes a political mobilization process. Social movement theories have long departed from mechanical grievance-based or psychological conceptions of collective action and reoriented the field to focus on politics, power, networks and organizations. Alongside motives, they stress at least three broad sets of factors usually designated as political opportunities, mobilizing structures and framing processes that need to be considered to explain social movements. A given institutional structure of national political systems and particular changes in political power relations both constitute the set of political opportunities and constraints underlying movement emergence. In turn, formal and informal pre-existing networks play a critical role in movement building. Identity formation, collective claim-making or protest are the products rather than the causes of interpersonal ties and organizational capacities. Demands successfully scale up to the national and transnational level, provided such networks pre-exist to enable interaction and mobilization. Last, collective action also presupposes the construction or dissemination of shared meanings and strategic situation definitions - framing processes - that provide the necessary conscious motivations and legitimation. These three static factors need to be considered in their dynamic interactions to account for movement emergence. For instance, while necessary, political opportunities are unlikely to be seized in the absence of organized networks. These structural conditions for collective action are not sufficient without shared frames. Networks and organizations are crucial for the diffusion of frames. Generalized perceptual changes, in turn, are necessary to allow objective political changes to be recognized as opportunities (McAdam et al., 1996).

Further developments in the social movement and contentious politics have built on this structural research programme and filled its gaps by trying to theorize on smaller scale constituent causal mechanisms and processes that underlie collective action. 
Networks and social ties are here readdressed not as static structures, but to observe how they enable interactions, information exchanges, new ideas, skills and trust-building. Attention is displaced to observe regular mechanisms such as different forms of diffusion, brokerage, attribution of similarity or emulation. Regular sequences of mechanisms, in turn, make up recurrent processes such as identity formation, coalition formation or scale shifts (McAdam et al., 2001; Tarrow, 2009; Tarrow and McAdam, 2005).

Converging with constructionist approaches in international relations, the study of transnational collective action has more recently developed as a subfield of social movement theory. The findings of social movement research offer insights for understanding the emergence of international non-government organizations (NGOs), transnational advocacy networks, coalitions and movements (Keck and Sikkink, 1998; Khagram et al., 2002; Tarrow, 2005; Tarrow and McAdam, 2005). In scaling beyond their localized beginnings and bridging their claims and identities, transnational activisms do not differ from national movements. Despite peculiarities, scale shift processes share different combinations of core mechanisms at both levels. Distant groups define themselves as sufficiently similar (attribution of similarity) or engage in similar action (emulation); transfers of information occur, either by impersonal carriers such as the mass media (non-relational diffusion) or along established lines of interaction (relational diffusion); previously disconnected groups bridge their narrow geographic or categorical boundaries identifying their shared circumstances through the action of brokers (Tarrow and McAdam, 2005).

Transnational activisms have assumed varied forms. Khagram et al. (2002: 9) define three incremental non-exclusive categories that can be ordered according to their level of collective action: transnational advocacy networks rest primarily on information exchanges, transnational coalitions require at least some coordination of tactics, and transnational social movements come about in the rarer presence of joint mobilization. Advocacy networks are usually built on informal configurations bonded together by shared values, discourses and exchanges of information, and services oriented towards change in an issue area (Keck and Sikkink, 1998). Although transnational actors may seek transnational outcomes, in many cases, transnational networks and coalitions are oriented towards domestic outcomes - policy change - through transnational tactics and processes used to influence the target actor. This ability to influence is based on the use of information, persuasion, moral pressure and, sometimes, legal action. International organizations are meeting places where these normative 'battles' with business and governments usually occur (Tarrow, 2005). Transnational activisms try to act on international standards and norms in different ways. They might try to transform their principled beliefs into international norms and policy standards. Existing norms might constitute political opportunities for activists to place pressure on governments. In some cases, these existing norms can help construct action frames. Groups can engage in 'frame bridging' or 'frame amplification' by building on already existing norms, but attempting to expand the domain to which these norms apply (Khagram et al., 2002: 16). As will be seen, several of these processes and mechanisms played an important role in the making of common policy agenda around media democratization and communication rights. 


\section{Democratic deficits: Media system structures in Latin America}

Given the historically low levels of newspaper circulation in all of Latin America, mass media have been associated with the expansion of broadcasting. The broadcast media, in turn, have developed historically as private commercial institutions under the influence of United States organizing principles and capital. This has been in contrast to Africa and Asia, where the state has monopolized the media, assigning them a central role in postcolonial nation-building. In Latin America, political elites have tended to leave the media field unregulated in exchange for control over political content. Media businesses have therefore been able to flourish as long as they have accommodated these limits. Where state media existed, their use as a governmental mouthpiece prevailed, leading to a lack of credibility and a marginal role in shaping audiences (Fox, 1988).

The late-20th-century transitions from authoritarian rule hardly included scrutiny of the media's role regarding democratic citizenship. Democratization in Latin America coincided with a dramatic expansion of the broadcasting industry and with broadcast television's consolidation as the dominant medium structuring national public spheres. Up to the 1970s, television was still a local, urban and middle- to upper-class phenomenon. From 1980 to 1996, the average number of television sets per 100 inhabitants jumped from 9.7 to 20.4 (Fox and Waisbord, 2002). By 2005, an average of 82 per cent of Latin American households possessed a receiver (Hughes and Prado, 2011). This expansion was matched by the consolidation of networks with unified programming reaching national coverage. In a context of vast newly enfranchised populations, this implied a revolution in political communication. Additionally, the industrial expansion and concomitant growth in the prestige of media institutions coincided with the $1980 \mathrm{~s}$ debt crisis, the worst socio-economic stagnation in Latin American history. This crisis resulted in a severe loss of credibility for parties and political institutions. In this new setting, media institutions, especially the newly forming conglomerates, acquired a new centrality and reputation as a power factor. Throughout the 1990s, surveys quite systematically showed media institutions' credibility ranking as second, close behind the Catholic Church and far ahead of all political institutions.

Subsequent neo-liberal reforms reinforced the described process in two ways, through the media outlets themselves and through socio-political structures. Market-oriented reforms profoundly transformed Latin America's media landscape in the 1990s. Privatization, the removal of cross-media ownership restrictions and the liberalization of new media industries resulted in concentration, conglomeration and transnationalization (Fox and Waisbord, 2002; Mastrini and Becerra, 2006). This further tilt towards a market logic reinforced problems related to a lack of diversity and the over-representation of privileged groups' interests and viewpoints (Hughes and Prado, 2011). But, at the same time, marketization did not 'eliminate the game of particularistic political pressures' and thus gave 'media interests new means to put pressure on politicians' through a change in balance. Persisting family control as the dominant ownership pattern, and the diminished dependence of media conglomerates on the state, turned these outlets into even more powerful political instruments for private corporate interests (Boas, 2013; Hallin and Papathanassopoulos, 2002). In broadcast television, ownership concentration is correlated 
with audience structure. While in Western democracies leading networks rarely share more than one-quarter of viewers, in Latin America the numbers range from one-third to over one-half of viewers (Boas, 2013; Hughes and Prado, 2011).

The impact of neo-liberal reforms on political representation structures also increased the relative importance of the mass media in the political process. The fragmentation of labour markets weakened trade unions and class organizations. The informalization of popular sectors meant that the unorganized masses outnumbered those capable of collective action around their class interests. In this context, popular mobilization increasingly came to depend on patronage or the mass media (Roberts, 2002).

In previous contexts, the media did not have such a pre-eminent role. In present-day Latin American democracies, media constitute the public space where symbolic struggles over representative claims occur. The quality of democratic representation depends not only on inclusion in political society but also on the inclusion of relevant social perspectives mediated in the public sphere. The media in Latin America have acquired the critical ability to determine the social visibility and legitimacy of interests and perspectives. In turn, the opportunity to make demands visible, and to have others recognize them as legitimate, affects the chances that political representatives will be responsive to them (Cottle, 2008; Porto, 2012).

This fact has become a burden for subaltern groups in Latin America. The location of the region's media system structures in a context of increasing social inequalities has had consequences for communicative power distribution and for the democratic process. Weak public and civic media, commercialization, conglomeration, persistent control by conservative elites and audience concentration have resulted in a mediated public sphere with a lack of diversity, inequalities in access, and content that - given the commercial, corporate and class incentives that govern content production - reflects the views and interests of elites and powerful groups in society (Boas, 2013; Hughes and Prado, 2011). However, these evaluations of political power distribution conditioned by media system structures come from external observers. They feature important motives; yet, collective action cannot be ascribed directly to these grievances or social cleavages (Tarrow, 2009).

In the realm of the media, given their nature as institutions that distribute symbolic goods, the discrepancy goes even further: inequalities in access and biased representations do not mechanically generate perceptions of injustice by the disadvantaged. Indeed, media representations of society are often functional to the reproduction of inequality. As critics stress, Latin American television tends to reinforce social distance, overexposing and making desirable the lifestyles of the rich for the poorer viewers, while leaving the rich ignorant of the life experiences of the poor, who are hardly visible except in the frame of crime and insecurity (Blofield, 2011; Hughes and Prado, 2011). In sum, while they have increased, structural inequalities within the media alone cannot explain when and how reformist demands emerged.

As previous attempts at media reform in the region demonstrate, certain conditions are necessary for demand mobilization. Particular organizational and framing structures have to mature and coincide with political opportunities. In the 1970s, after a regional advocacy network had succeeded in mobilizing around 'national media policies', almost all of the region's countries had reverted to military authoritarianism (Fox, 1988; Ramos, 2010). 
This story of failure offers clues regarding uninterrupted political democracy as a condition that provides the necessary associational space. In fact, never before have so many democracies endured for so long in Latin America. The unprecedented continued exercise of political rights by large, enfranchised populations against a background of unequally distributed political resources has worked as a necessary (though not sufficient) condition to bring the issue of the media to the forefront. Political democracy has provided the necessary space for subsequent developments. Although intertwined, these developments will be first looked at attending to three analytically different levels identified in movement theory: domestic civil society, transnational civil society and political alignments.

\section{Domestic civil society}

A series of domestic-level processes, observable in most of Latin America since redemocratization, led to the proliferation of formal and informal networks that would later play a critical role. The above-mentioned media growth in the region has corresponded with the increasing professionalization and diversification of media roles. The demand for special media skills and technical knowledge has been reflected in the proliferation of educational and professional institutions. From the second half of the 1980s, the whole region experienced an exponential growth in communications and journalism schools. In 1984, the number of university-dependent communications schools in Latin America was 187; in 1992, there were 271. This number had jumped to 1025 in 2005 (Mellado, 2010). Many of these institutions attracted social scientists, experts and intellectuals, around whom the critical scrutiny of media performance and policies constituted a relatively autonomous field. But the economic and political impact of media institutions also led other related organizations such as professional associations, unions and foundations to become increasingly concerned with debates about media influence. While these organizations frequently stemmed from conservative or confessional groups concerned with the 'quality' or 'morality' of media content, there were also several progressive secular groups that formed media observatories oriented towards issues of cultural diversity, concentration and influence of economic and political power in the media (Albornoz and Herschmann, 2008).

Although community radio stations linked to churches, rural education or the unique Bolivian miners' union had existed in Latin America prior to the wave of democratization, they flourished in its aftermath. The reduced repression and the lowering costs of radio equipment led to the proliferation of such alternative media not only in rural communities, but also in urban areas. This very heterogeneous phenomenon demonstrated divergent linkages and motivations and was driven by social movements, communications students, political activists and grass-roots organizations, as well as small and informal profit-oriented broadcasters. Organizations aimed at providing technical training, creating funding mechanisms and discussing the legal status of alternative broadcasting gradually grew out of these new social actors. Their major commonality was that they were illegal. This condition was itself difficult to overcome, given the stiff opposition to their recognition on the part of the commercial broadcasters. Therefore, the removal of legal barriers informed early mobilizations and oriented organizations 
primarily towards legislative lobbying and judicial struggles for legalization, which would ease the framing of their demands in terms of rights (Bresnahan, 2007; Hintz, 2015; Klinger, 2011).

Yet a parallel development would facilitate brokerage and the spreading of media reform demands beyond narrow media activists. With re-democratization, social movements and advocacy groups working on the most disparate issues proliferated in Latin America. This sustained mobilization in support of class, ethnic, gender, environmental and other demands corresponded to an expansion of media-critical perspectives. The causal mechanism underlying this correlation was the necessity of public visibility, legitimacy and support for success in having these demands met. ${ }^{2}$

In contemporary democracies, mainstream news media have become central to the expression and representation of demands and dissent. This has meant that social mobilization and protest have come to be reflexively conditioned. In Western countries, recent changes in public attitudes towards protest, political alignments and media ecology have allowed movements to develop reflexive tactics that defy the delegitimizing media frames as the only possible outcome (Cottle, 2008). While this trend may eventually come to apply to Latin America, its conditions contrast in a context characterized by an elite-dominated broadcasting media and the conservative, middle-class orientation of the public and of journalism. When not ignored, social movements have been predominantly framed in negative ways in the news, with violent behaviours and the criminal nature of the actions emphasized (Da Silva and Rothman, 2011; Porto, 2012).

In this context, as informants attested, mobilization around specific demands has expanded various groups' susceptibility to media representations and raised concerns about stereotypes, biases, and so on. Several mobilization episodes in the region, especially during the wave of anti-neo-liberal protest, attest to the increase in media-critical perceptions. To mention only one prominent example, in Bolivia, the biased coverage of the ethnic and popular mobilization that later brought Evo Morales to the presidency blatantly exposed the media owners' own political interests (Lupien, 2013).

In such contexts, and - as will be seen - given the proper political conditions, the scattered claims towards the media from diverse non-media specific social groups coalesced with media-related groups to form broad media reform movements, framing their demands in the common denominator of communication rights. As a Communications School dean and member of the Uruguayan Coalition for Democratic Communications described the scenario after the electoral victory of the Left,

$[\mathrm{T}]$ he feeling that now it was serious business glued us together. It motivated the effort to find a common ground and harmonize the particular demands with consumer associations, feminists, children's rights groups and other movements around a media regulatory reform program.

Several interviewees agreed that the language of communication rights and media access provided the strategic flexibility and the common terrain for bridging particular demands that allowed the construction of broad media reform coalitions, including non-media specific movements. 


\section{Transnational civil society and networks}

The emergence of the media democratization demands in Latin American cannot be understood without paying attention to transnational civil society, defined as a series of different processes involving advocacy networks and actions that cross national borders and that have been growing since the 1990s. These processes have comprised various phenomena.

An initial feature has been the growth and regional involvement of international NGOs (INGOs). Since the 1980s, opportunities to establish networks that blur the line between domestic and transnational activists have flourished. These international advocacy networks have mostly been funded by multilateral organizations, Northern development agencies or large foundations.

Communications researchers and educational institutions have increasingly formed regional organizations such as the Asociación Latinoamericana de Investigadores de la Comunicación (ALAIC) or the Federación Latinoamericana de Facultades de Comunicación Social (FELAFACS). The International Journalists Federation, which is an association of journalist unions from around the world, created its Latin American chapter in 1990. Community media groups have also formed regional networks. Broadcasters linked to progressive Catholics formed the Asociación Latinoamericana de Educación Radiofónica (ALER) and the Organización Católica Latinoamericana y Caribeña de Comunicación (OCLACC). In 1990, the World Association of Community Radio Broadcasters (AMARC), which has the aim of radio frequency redistribution, created its Latin American chapter. It is presently operating in 18 countries in the region and has more than 400 affiliates.

As many informants noted, these transnational networks helped to reinforce the domestic legitimacy of activism, to circulate information, and to diffuse local experiences through regular meetings, workshops and personal contacts. Over the course of the 1990s, some of these INGOs and other groups started collaborative processes, including exchanges and joint actions. The various regional seminars and encounters fostered common problem definitions and led to a series of declarations, in which the notions of media democratization and rights to communication emerged as common denominators.

Regional diffusion of academic research provided activist networks with information, conceptual definitions and scientific legitimacy to make policy claims. A prominent example refers to the case of two region-wide studies conducted by two Argentinean scholars financed by Open Society and the Ford Foundation to measure media concentration in the region (Becerra and Mastrini, 2009; Mastrini and Becerra, 2006). The two books were key to defining media concentration as a region-wide policy problem. As one of the authors much later reflected,

while it was widely perceived, no systematic data on media concentration was previously available [...] however, we did not expect the books to have such an impact, not only among fellow scholars, but especially among activists, in documents and manifestos. We even detected that public officials and legislators had read the books. After they were published we were invited to all sort of seminars and events throughout the region.

The networking processes were further facilitated by the proliferation of transnational events organized by anti-neo-liberal groups as counter-events - proposing alternative 
agendas - to establishment forums (Tarrow, 2009). A relevant occasion in this respect was the World Summit on the Information Society, a UN-sponsored event held in 2003 and 2005 and organized by the International Telecommunication Union for the purpose of discussing the international regulation of digital convergence. Civil society was granted a 'carefully limited' space for participation alongside government and business interests. Their participation took the form of a campaign called Communication Rights in the Information Society (CRIS), which counter-framed the issues and policy orientations of the summit in terms of human rights and social dimensions instead of technology. This participation led to further transnational networking and sustained civil society's appetite for organized input into international institutions. The coalition that conducted the CRIS campaign was made up of a number of INGOs with a strong Latin American presence (Segura, 2014).

However, it was the World Social Forum (WSF), the most noteworthy of these counter-summits, which played a key role as broker, connecting media activists with a wider network of social movements and civil society actors. Organized in response to the World Economic Forum, the economic elite summit held yearly in Davos, the WSF began in 2001 in Porto Alegre and consolidated as a regular meeting of a broad spectrum of movements, unions and other social groups. A wide range of media-critical voices were present at the WSF, from radical movements that supported counter-hegemonic communication to reformist advocates of media pluralism and democracy.

A final but central feature in transnational developments has been the regional states' signing of conventions and their adherence to transnational juridical regimes. These have included the United Nations Educational Scientific and Cultural Organization (UNESCO) Convention on the Promotion and Protection of Cultural Expression Diversity and the Inter-American Convention on Human Rights, which instituted transnational juridical regimes such as the Inter-American Commission on Human Rights (IACHR) and its court, the Inter-American Court of Human Rights.

In fact, the IACHR is an example of an international organization that offers venues for civil society organizations to undertake transnational legal activism. The making of strategic demands within transnational courts has occurred in contexts of blockage or where there has been a lack of responsiveness to domestic demands. It consists of activists going outside their own states in order to advance their constituents' goals inside the state (Tarrow, 2005). In Latin America, the opportunities these institutions had previously offered to organizations struggling against human rights violations under authoritarian regimes subsequently encouraged domestic actors to frame broader claims in terms of rights. Groups making gender- and ethnicity-related, environmental and other demands have attempted this road. Therefore, the reframing of media democratization demands in terms of communication rights or conflicts over freedom of expression has been part of a broader frame bridging process.

Unsurprisingly, the first groups to utilize judicial strategies based on reframing mediaspecific demands came from Argentina, a country with a significant record of struggles to redress human rights abuses from the past. There, a group of legal activists networked with human rights organizations to pioneer the use of legal strategies (in domestic and transnational courts) that began to challenge the prevalent, narrow understandings of freedom of expression as media owners' press freedom. In fact, the IACHR gradually 
became the central reference point for INGOs - such as AMARC - in transmitting liberal-egalitarian views supporting media pluralization (Klinger, 2011; Mauersberger, 2011).

These links between civil society and international organizations led to the gradual transformation of both types of entity. Strategic collaboration with international organizations biased civil society organizations' recruitment practices, making them favour professionals with legal-academic skills that would support insider advocacy strategies. The international organizations' growing interaction with civil society organizations because they were frequently the target of the latter's demands - gradually broadened these organizations' understandings of freedom of expression, which thereby became increasingly linked to pluralism and democracy. As a former AMARC legislation programme director noted, this transformation was crucial to the establishment of a regional agenda calling for greater media diversity, and especially for recognition of the role of community media.

\section{Elite realignments}

Examining political opportunities and constraints is crucial when tracing how underlying structural factors and mobilization potential transform into action. Conflicts or splits among the elites and the perceived availability of elite allies are critical in encouraging mobilization. The incentives are twofold: divisions among elites encourage resource-poor groups to take up collective action, while the dissident portions of the elites are tempted to take up potential demands and play the role of 'tribunes of the people' (Tarrow, 2009).

These dynamics of reciprocal opportunities are central to grasping the timing of the contentious politicization of media reform in Latin America (Segura, 2014). In the previously described setting of media expansion and simultaneous socio-economic crisis, the media were increasingly perceived by political elites as central players ('de facto powers') capable of shaping the political process (PNUD, 2004). On one hand, the media were seen as capable of positioning public agendas and influencing policy; on the other, they were seen as having the power to control the careers and reputations of political officials. Because public officials ascribed the media greater influence than may have actually been the case, their perceptions became as good as real, since they made decisions in anticipation of media reactions. As a consequence, these perceived media effects provided media owners with great lobbying power, placing them in a position to capture the state and veto key decisions that may have affected their dominance (Hughes and Prado, 2011). In light of this increasing reputational power, the dominant strategy of political elites was to accommodate the media elites.

The crisis surrounding the Washington Consensus and the rise of the so-called New Left in the region changed the political scenario. The economic crisis that spanned from 1998 to 2002 changed the climate of opinion. As a promise of incorporation into modernity, the hegemony of the Washington Consensus was exhausted when, after the economic downturn began in 1998, hardship began to be widely felt by growing sectors of Latin America's population. This brought the issues of equality and redistribution and the search for policy alternatives to the forefront. In this context, political incumbents who 
had sustained market-oriented reforms tended to be voted out of office, while leaders who promised to steer away from 'neo-liberalism' tended to achieve electoral success, reinforcing, in turn, the seeking of a new post-neo-liberal consensus around progressive politics (Levitsky and Roberts, 2011).

The 'Left turn' represented a change in governmental elites that destabilized the existing politics-media alignments. In the Andean countries, political outsiders such as Hugo Chávez, Evo Morales and Rafael Correa took office and promised radical change. In countries such as Brazil and Uruguay, the social and political origins of the new governments were alien to establishment groups. Despite their more recent moderation, these new governments' members tended to hold critical views of establishment media (Kitzberger, 2010).

It was an early episode that signalled the end of the accommodation between the media and the political elites as the only game in town. After the direct participation of Venezuela's most important media moguls in the attempted coup in April 2002, it was Chávez who opened the path to confrontation with the established media. During the crisis, the private stations gave exclusive and uninterrupted coverage to the opposition. On 11 April, army officials detained Chávez and announced that he had resigned. The private media outlets did not question this statement. Meanwhile, they aired manipulated images showing Chavistas firing arms against an oppositional rally. On the eve of the coup, the conspirators had managed to take the state television station off air. In the following days, the media silenced loyal army officials and ignored the massive pro-Chávez rallies. Ultimately, these latter mobilizations, the divided military and key defections among the putschists drove Chávez back to the presidency. While Chávez's relationship with the media had been tense before, it was only after this juncture that he steered towards open confrontation (Kitzberger, 2010).

Although it was not mechanically emulated in terms of tactics and counter-hegemonic repertoire, the Venezuelan experience had a learning effect. Its importance lay in the fact that it signalled to other regional governments that political survival was possible without accommodation of the media elite. Some of the leftist presidents, such as Correa and Morales, opted for confrontation with the established media immediately after taking office. Other political leaders, such as the Kirchners, experienced an initial phase of accommodation with the media elites, followed by a phase of conflict and confrontation. The more moderate party-led leftist governments of Brazil and Uruguay did not unleash media wars; however, their governments struck a balance between accommodation and conflict with the traditional media institutions, opening up space for media reform demands.

\section{Interactions}

The developments in the spheres of domestic civil society, transnational civil society and political alignments - which have been treated separately in the previous three sections -interacted in complex ways to bring about a reformist agenda. Two processes involving several enabling mechanisms can be traced. A process of scale shift was unleashed by the political turn to the left, while another process linked to the expansion of transnational activism shaped the framings, shared understandings and policy guidelines. 
The regional change in the political opportunity structure was one of the main triggers of the spreading of media reform demands. Among the group of New Left presidents, the cordial relationships and group identity, which transcended the differences between moderates and radicals, reinforced diffusion of strategic repertoires and learning mechanisms. As a journalist who functioned as a media advisor to the Argentine presidency stated, early on, the Kirchners were extremely attentive to the media politics of Chávez and the other regional governments. The latter's example signalled, as said, the existence of confrontation with media elites as a political option.

In turn, the shift towards a general regional climate of political willingness to question the media and the resounding media critiques stemming from executive leaders in the common Spanish-speaking and increasingly networked cultural space worked as an incentive within civil society to further organize and mobilize so as to be prepared for an increasingly perceived as feasible governmental opening towards the reformist agenda. This climate even expanded to Portuguese-speaking and previously isolated Brazil. As a Brazilian communications scholar noted, 'our outlooks have historically been very provincial, the regional left turn presented us with a new mirror to look at and gain insights in our struggles with the big media'.

The example of Argentina illustrates the reciprocal character of interactions between political and social actors. Although the government's main strategy during Néstor Kirchner's presidency was to maintain a pragmatic alliance with the dominant Clarín conglomerate, the various groups in civil society sensed that the context had changed. That perception encouraged the formation of a broad coalition, the Coalición para una Radiodifusión Democrática (CRD), to develop a unified minimal reform programme, the '21 points', should the opportunity arise (Mauersberger, 2012). In turn - and similarly to what occurred in the context of the agrarian crisis, in which the Kirchner government's pragmatic understanding with Clarín crumbled - the presence of a unified and mobilized movement, whose reform proposal was backed by the UN rapporteur for freedom of expression and was recognized as conforming to the inter-American standards for freedom of expression, served as an incentive for the government to risk the move.

As several informants reported, relational and non-relational diffusion of ideas and framings operated in this more favourable political context at the level of civil society actors. Relational diffusion occurred through the pre-existing networks. The increasingly interconnected civil society actors looked to each other, drawing important lessons in the process. The prior personal ties between media activists and epistemic communities were, in turn, significantly reinforced as the reform-friendly regional governments eased access to state resources for special conferences, seminars, documents, investigative commissions and special events related to policy reform.

As some informants reported, the media coverage of government-media conflicts and policy change in neighbouring countries also played a part in spreading information and in issue adoption.

These interactions, based on intense interpersonal ties and cultural proximity, are easily visible in the example of neighbouring Argentina and Uruguay. The former country's reform movement coalition adopted substantial elements that the latter's civil society groups had successfully promoted in the 2007 Community Broadcasting Law; later, after Argentina had passed its Audiovisual Communication Services Law in 2009, Uruguayans 
silently took it up as a model for their country's own media law, which was passed in 2014 (Mauersberger, 2011).

Once the 2009 law was passed, the political mobilization process that preceded the regulatory reform in Argentina became a closely watched model for the other countries in the region. Many activists reported having travelled to Argentina during the public audiences and legislative debates around regulatory reform. Members to the Argentinean reform coalition, the CRD, were invited throughout the region to transmit the experience. As an Ecuadorean activist put it, 'our task was not about inventing hot water, there was a successful experience, so we invited some of the key players from the Argentine process'. The CRD strategies were adopted as a model. 'Inspired by the Argentine 21 points', a Brazilian reform coalition member admitted, 'in 2011 we elaborated a document [Plataforma 2011] with the main principles that can gather support of diverse social groups and that will allow us to react promptly in case the government opens the door to media reform'.

Parallel to the mobilization unleashed by the political shift to the left, the rise of transnational activism that operates in the arena of international organizations decisively shaped the reformist agenda. While international human rights norms expanded their domain to media and communications, representing a case of frame bridging, the activist networks also provoked normative change by affecting interpretations of freedom of expression and policy standards.

As said, international organizations can represent opportunity structures for non-state actors and constraints for state actors with regard to certain policies. Conversely, their guidelines, standards and agendas can be influenced by their interactions with civil society. Evidence of such effects can be found at the level of jurisprudence within the interAmerican legal system. In fact, IACHR understandings of freedom of expression have significantly changed since transnational legal activists initially began to resort regularly to the court and the commission. Until the year 2000, the commission's freedom of expression rapporteur's yearly reports only recognized cases in which the autonomy of speakers (individuals or media outlets) was threatened (mainly by state interference). In this classic liberal view, the only legitimate role of the state is avoiding interference. Freedom of expression was unilaterally interpreted in this negative way, despite the fact that in US Supreme Court rulings and in European jurisprudence, another established tradition existed based on the understanding of freedom of expression as a function of democratic self-government rather than of individual self-realization. This Latin American jurisprudential attachment to negative freedom had its roots in authoritarian memories that determined widespread distrust of the state. However, such an interpretation prevented the inclusion of the mounting regional problem of media concentration as a potential menace to freedom of expression (Fuentes Torrijo, 2002).

Democratic freedom of expression requires that the state undertake the positive task of avoiding the limitation of diverse voices by economic or technological factors in the constitutively limited public sphere. Far from limiting freedom of expression, proper state intervention enhances the open and pluralist debate required by democracy. By 2010, the inter-American system's jurisprudence explicitly assimilated this second interpretation by recognizing the 'double dimension of freedom of expression'. In the IACHR's present agenda and policy recommendations, the freedom of 
expression rapporteur assumes that freedom of expression is essential to 'collective self-determination' and, therefore, that states must generate the conditions for a public, plural and open debate (IACHR, 2010). In order for states to do so, the commission continues,

[I]t is the obligation of States to subject ownership and control of the media to general antitrust laws to prevent de facto or de jure concentration that restricts the plurality and diversity needed to ensure the full exercise of the citizens' right to information. Likewise, [...] the allocation of radio and television must consider democratic criteria that guarantee true equality of opportunity for all individuals in their access to them. (IACHR, 2010)

The above-mentioned interactions helped to bring about a regional media policy agenda whose goals (pluralism, diversity) and instruments (antitrust legislation, concentration limits, cross-ownership bans) are shared by most Western post-war democracies (despite their present-day retreat from them). However, the interactions also helped develop unique policy instruments. The provision of spectrum reserves for community broadcasting has no precedents in other legal regimes. Its development can be traced back to the commercial sector's fierce historical opposition to community actors and the latter's subsequent process of mobilization, but its diffusion and generalization in legislation owe much to the recognition, praise and promotion it received from organizations such as UNESCO and IACHR (Mendel, 2013). In fact, the IACHR

has considered fundamental the recognition of so-called community radio and has indicated, for example, that auctions that take into account only economic factors or that grant concessions without equal opportunity for all sectors of society are incompatible with democracy and with the right to freedom of expression and information guaranteed in the American Convention on Human Rights and in the Declaration of Principles on Freedom of Expression. (IACHR, 2010)

Thus, the jurisprudential shift and the evolution of the media-related policy standards can only be understood when viewed in the context of the regular interactions between international organizations and the strategic legal activism undertaken by civil society. As a legal advisor to AMARC and key member of the Argentine reform coalition recalled, 'the Inter-American Human Rights System was sensitive in this regard and backed us decisively, if something advanced during these years it was the recognition in terms of rights of community broadcasting'.

In sum, this article has shown how certain processes of social mobilization and transnational activism, together with changes in political elite alignments and their mutually reinforcing interactions, have brought about a regional policy agenda oriented towards media democratization goals that respond to historical grievances and deep structural inequalities in Latin America's media systems. This agenda is now evident in the demands of organized civil society, in the media reform movement and in unprecedented public debates. It has also gained expression in domestic and regional jurisprudence and in the policy recommendations and standards of regionally influential international organizations. Its policy goals and instruments are increasingly present in several new regulatory media and communications laws and in a number of public policies that strengthen market-alternative logics in the media field. 
General orientations and values such as democratic freedom of expression and communication rights inform policy goals such as pluralism, diversity and equal media access. Most of the policy instruments intended to pursue such goals - such as crossownership bans, licence concentration limits, market share caps, subsidies and public broadcasting - are classic and common in media legislation oriented to political welfare objectives. Others, such as the provision of spectrum reserves for community broadcasting, have no precedents in other legal regimes (Mendel, 2013).

However, what makes the policy agenda in Latin America distinctive is the emphasis on the active role of the state as a guarantor of pluralism and diversity and as a compensator for social and market inequalities in the public sphere, at a time when the rest of the world's '[g]overnments are retreating from regulation where it interferes with market development and giving relatively more priority to economic over socialcultural and political welfare when priorities have to be set' (van Cuilenberg and McQuail, 2003). As Waisbord (2013) has observed, Latin America's domestic processes attest to the presence of important counter-tendencies to market-driven globalization in the media realm.

\section{Conclusion}

This article traced the processes that led to the emergence of Latin America's distinct media policy agenda. It showed how the context of re-democratisation and media expansion led to the formation of a network through which media reform demands would gradually organize. These demands spread beyond specific media activisms once media access started appearing as crucial to other-issue movements. The forming advocacy networks grew beyond national borders through Northern public and private funding of INGOs, through the brokerage of anti-neo-liberal transnational events and campaigns, and through the availability of venues offered by transnational organizations and courts. These forms of strategic claim-making were conditioned by and reinforced the framing of the agenda in terms of rights to freedom of expression, pluralism and diversity. All these developments interacted and were reinforced - although not caused - by the post1998 political shift to the left, resulting in the decisive scale shift in the mobilization around the reform agenda.

Despite its regional character, the reform agenda did not permeate public policy in all of the region's countries. In the cases where no leftist challenger came to government, reform agendas remained mostly blocked. Except for minor concessions for community radio, there have been few chances to push for reforms, as the cases of Colombia, Peru and Mexico demonstrate. Only the 'Left turn' cases have provided significant opportunities for legal reforms. However, in these latter cases, similar demands and pressures for media democratization resulted in different regulatory outcomes. These variations have depended on the nature of the actors, the relations of force and the specific features of the various political processes. Even in Brazil, despite its important reform movement linked to the governing Workers' Party, the legislative coalition with non-leftist parties vetoed the attempts at legal reform.

Moreover, the transformation of this agenda into consistent public policies that can achieve the effective democratization of the public sphere faces serious challenges. 
There are long-run challenges undermining consistent media reform policies such as the overall weak capacity of the region's state institutions to implement decisions following universalist rules - especially when elite interests are at stake - and the strongly embedded practices of instrumentalization and clientelism in the media politics relationships (Hallin and Papathanassopoulos, 2002).

Other challenges belong to the present of polarized politics in the region. While the reform agenda achieved substantial mobilization, political society in Latin American democracies is deeply divided. In this context, the media democratization agenda in the region has been a contested one.

Especially in the polarized political setting of leftist populism, anti-populist oppositions - frequently headed by media organizations - have tended to question media democratization policy initiatives, viewing them as façades to hide attempts to control the press. The inclusion of controversial provisions on content regulation in the legislative reforms undertaken by the Andean populist governments have only reinforced this questioning and further polarized and impoverished the debates. ${ }^{3}$

But contestation is not just a feature of the populist contexts. Even in the less polarized cases, there is scarce support and even resistance for democratic media reforms beyond a mobilized civil society and the political Left. A significant share of Latin American political elites still relies on dominant-media accommodation. The case of Uruguay is illustrative in this respect. Reform measures were passed there exclusively with the votes of the leftist majority. The whole of the opposition voted against them in Congress and voiced harsh criticisms, promising to reverse them once it came to power.

In fact, the regional cycle of progressive governments may be coming to an end. Recent elections and political events, such as the crises in Brazil and Venezuela, point to a turn of the political tide. In December 2015, a centre-right government was elected in Argentina. A few weeks after assuming power, President Mauricio Macri released several decrees that repealed the core of the 2009 media reform law by removing almost all of the 2009 media law's provisions that restrict media ownership concentration, despite their being held constitutional by the Supreme Court of Justice in 2013. Especially in the realm of cable television (about $80 \%$ of the country's audiences), it completely lifted any limits on audience caps, licence numbers and all of the 'must carry' obligations. The decrees eliminated public service obligations for broadcasters by treating licences as market commodities, expelled civil society representatives from regulatory agencies and created a new Executive-dependent authority. This policy reversal has been rhetorically justified claiming that it constitutes the endpoint of the populist politics of curbing 'independent journalism' and the beginning of a new framework allowing modernization and digital convergence. At the time of this writing, members of the advocacy network that stood behind the 2009 law are trying to block these regulatory changes by resorting to the IACHR. The results of this resort to transnational legal mobilization remain open. In addition to this setback in a country that functioned as a leading example of media reform, almost all of the other left-leaning governments in Latin America show signs of political exhaustion. In this new scenario, the activist networks that promote democratic media reforms will face difficult times in sustaining their agenda. 


\section{Funding}

The author(s) received no financial support for the research, authorship, and/or publication of this article.

\section{Notes}

1. The interviews comprise media reform-related roles such as members of advocacy NGOs from the communications field, community media activists, academics from communication studies, media workers, union members, journalists, state officials and legislators. Fieldwork was conducted during June-July 2011 in Brazil, April 2011 and June 2012 in Ecuador, July 2012 and June 2014 in Argentina, and September 2015 in Uruguay.

2. A quantitative study on civil society and communication policies in the United States found that the fastest growth of communication policy advocacy groups occurred in the 1960s and 1970 s, simultaneous to the emergence of advocacy groups covering issues of environmentalism, civil rights and gender (Mueller et al., 2004).

3. Chávez and Correa have rejected the IACHR criticisms of such provisions. In their more radicalized views, the human rights standards for freedom of expression promoted by the inter-American system constitute a neo-liberal intervention.

\section{References}

Albornoz L and Herschmann M (2008) Ibero-American observatories in the sectors of information, communication and culture: A brief history. Media, Culture \& Society 30(5): 723-734.

Becerra M and Mastrini G (2009) Los dueños de la palabra: Acceso, estructura y concentración de los medios en la América Latina del Siglo XXI. Buenos Aires, Argentina: Prometeo.

Blofield M (2011) Desigualdad y política en América Latina. Journal of Democracy en Español 3: $58-74$.

Boas T (2013) Mass media and politics in Latin America. In: Dominguez J and Shifter M (eds) Constructing Democratic Governance in Latin America. Baltimore, MD: Johns Hopkins University Press, pp.48-77.

Bresnahan R (2007) Community radio and social activism in Chile 1990-2007: Challenges for grass roots voices during the transition to democracy. Journal of Radio Studies 14(2): $212-233$.

Cottle S (2008) Reporting demonstrations: The changing media politics of dissent. Media, Culture \& Society 30(6): 853-872.

Da Silva PP and Rothman FD (2011) Press representation of social movements: Brazilian resistance to the Candonga Hydroelectric Dam. Journal of Latin American Studies 43(4): 725-754.

Fox E (1988) Media and Politics in Latin America: The Struggle for Democracy. London: Sage.

Fox E and Waisbord S (2002) Latin Politics, Global Media. Austin, TX: University of Texas Press.

Fuentes Torrijo X (2002) La protección de la libertad de expresión en el Sistema Interamericano de Derechos Humanos. Revista De Derecho 13: 225-255.

Goertz G and Mahoney J (2012) A Tale of Two Cultures: Qualitative and Quantitative Research in the Social Sciences. Princeton, NJ: Princeton University Press.

Gómez García R (2013) Media reforms in Latin America: Between de-commodification and marketization of communication public policies. Mediawatch Journal 44-45: 78-79.

Hallin D and Papathanassopoulos S (2002) Political clientelism and the media: Southern Europe and Latin America in comparative perspective. Media, Culture \& Society 24(2): 175-195.

Hintz A (2015) Towards community and non-profit media legislation in South America: Challenging media power through citizen participation. In: Martens C, Vivares E and McChesney R (eds) 
The International Political Economy of Communication: Media and Power in South America. London: Palgrave Macmillan, pp.46-62.

Hughes S and Prado P (2011) Media diversity and social inequality in Latin America. In: Blofield M (ed.) The Great Gap: Inequality and the Politics of Redistribution in Latin America. University Park, PA: Pennsylvania University Press, pp.109-147.

IACHR (2010) A Hemispheric Agenda for the Defense of Freedom of Expression. Washington, DC: Office of the Special Rapporteur for Freedom of Expression Inter American Commission on Human Rights.

Keck M and Sikkink K (1998) Activists beyond Borders: Advocacy Networks in International Politics. Ithaca, NY: Cornell University Press.

Khagram S, Riker J and Sikkink K (2002) From Santiago to Seattle: transnational Advocay Groups Restructuring World Politics. In Khagram S, Riker J and Sikkink K (eds.) Restructuring World Politics: Transnational Social Movements, Networks and Norms. Minneapolis, MN: University of Minnesota Press.

Kitzberger P (2010) The media activism of Latin America's leftist governments: Does ideology matter? GIGA working paper no. 151, November. Hamburg: GIGA.

Klinger U (2011) Democratizing media policy: Community radios in Mexico and Latin America. Journal of Latin American Communication Research 1(2): 1-19.

Levitsky S and Roberts K (eds) (2011) The Resurgence of the Latin American Left. Baltimore, MD: Johns Hopkins University Press.

Lupien P (2013) The media in Venezuela and Bolivia: Attacking the 'bad left' from below. Latin American Perspectives 40(3): 226-246.

McAdam D, McCarthy J and Zald M (eds) (1996) Comparative Perspectives on Social Movements: Political Opportunities, Mobilizing Structures and Cultural Framings. Cambridge: Cambridge University Press.

McAdam D, Tarrow S and Tilly C (2001) Dynamics of Contention. Cambridge: Cambridge University Press.

Mastrini G (2013) Progressive governments and communication media in South America. Mediawatch Journal 44-45: 74-77.

Mastrini G and Becerra M (2006) Periodistas y magnates: Estructura y concentración de las industrias culturales en América Latina. Buenos Aires, Argentina: Prometeo.

Mauersberger C (2011) Whose voice gets on air: The role of community radio and recent reforms to democratize media markets in Uruguay, Argentina and Chile. Journal of Latin American Communication Research 1(2): 1-24.

Mauersberger C (2012) To be prepared when the time has come: Argentina's new media regulation and the social movement for democratizing broadcasting. Media, Culture \& Society 34(5): 588-605.

Mellado C (2010) Reflexiones sobre la oferta académica, la situación laboral y la formación del periodista en Latinoamérica. Revista De Ciencias Sociales 15(1): 9-20.

Mendel T (2013) Tuning into Development: International Comparative Survey of Community Broadcasting Regulation. Paris: UNESCO.

Mueller M, Pagé C and Kuerbis B (2004) Civil society and the shaping of communication-information policy: Four decades of advocacy. Information Society 20(3): 169-185.

PNUD (2004) La democracia en América Latina. Buenos Aires, Argentina: Programa de Naciones Unidas para el Desarrollo.

Porto M (2012) Media Power and Democratization in Brazil: TV Globo and the Dilemmas of Political Accountability. New York: Routledge.

Ramos M (2010) Possibilidade de uma nova agenda para as políticas de comunicação na América Latina. RECIIS 4(4): 20-28. 
Roberts K (2002) Social inequalities without class cleavages in Latin America's neoliberal era. SCID 36(4): 3-33.

Segura MS (2014) La sociedad civil y la democratización de las comunicaciones en Latinoamérica. Íconos: Revista De Ciencias Sociales 49: 65-80.

Tarrow S (2005) The New Transnational Activism. Cambridge: Cambridge University Press.

Tarrow S (2009) Power in Movement: Social Movements and Contentious Politics. Cambridge: Cambridge University Press.

Tarrow S and McAdam D (2005) Scale shift in transnational contention. In: Della Porta D and Tarrow S (eds) Transnational Protest and Global Activism. Lanham, MD: Rowman \& Littlefield, pp.121-151.

van Cuilenberg J and McQuail D (2003) Media policy paradigm shifts: Towards a new communications policy paradigm. European Journal of Communication 18(2): 181-207.

Waisbord S (2010) The pragmatic politics of media reform: Media movements and coalitionbuilding in Latin America. Global Media and Communication 6(2): 133-153.

Waisbord S (2011) Between support and confrontation: Civic society, media reform and populism in Latin America. Communication, Culture \& Critique 4: 97-117.

Waisbord S (2013) Media policies and the blindspots of media globalization: Insights from Latin America. Media, Culture \& Society 35(1): 132-138.

\section{Author biography}

Philip Kitzberger is a researcher at the National Scientific Research Commission of Argentina (CONICET) and Professor of Political Science at the Universidad Torcuato Di Tella in Buenos Aires. 